\title{
INDUSTRIAL RESEARCH IN BRITAIN
}

$R^{E}$ ESEARCH for Industry, 1963* reports briefly on the progress made by nine research associations the grants of which were reviewed during the year. The British Coke Research Association's investigations of the conditions necessary for improving the quality of coke from a medium-quality coking coal, such as will be carbonized in increasing quantities, have already led to improvements in the consistency and quality of the coke by controlling the bulk density of the charge, adjusting the size and water content of the coal, and admixing small amounts of oil. By adding three different materials to poor coking coal, the physical properties of the coke have been improved sufficiently for it to be suitable for use in blast furnaces. Investigations on foundry coke, in collaboration with the British Cast Iron Research Association, have indicated procedures extending the range of coke suitable for foundry use, and a major achievement in the domestic field has been the demonstration that certain additives give a coke of improved reactivity. Fundamental investigations of the thermal behaviour of coal and the fissuring of coke promise to illuminate the process of fissure formation during carbonization of coal in coke ovens.

Fundamental work by the Research Association of British Flourmillers has included investigations of the amino-acid composition of the total protein of different types of flour, comparison of the individual fractions of the protein and an examination of the interrelation of the disulphide and thiol groups. A new family of at least six anti-oxidants has been isolated from oats and wheat, and development of the air classification of flour continued. Replacement of at least 25 per cent of the malted barley by a low-protein English flour has given beer with a better head and keeping properties. The Fruit and Vegetable Canning and Quick Freezing Research Association has continued its investigations of the heat-resistance of micro-organisms which might be present in the canned products before heat processing. Its work on the chemistry of processed peas in relation to texture is nearing completion, and a survey is being made of the extent of contamination of quick frozen foods by various types of bacteria.

The Gelatin and Glue Research Association has initiated an investigation of the fine structure of collagen and has prepared many derivatives of gelatin and animal glue by substitution of the amino-groups present. Methods have been evolved for determining the degree of substitution, and also for increasing the cross-linkability of certain bone glues. Extra-mural support is being given to an investigation at Cambridge on the ultracentrifugation of gelatin gels, and there has been further

- Department of Scientific and Industrial Research. Research for Industry, 1963; a Report on work done by Industrial Research Associations in the Government Scheme. Pp. $\mathbf{v}+54+19$ plates. (London: H.M. Stationery Office, 1964.) 58.6d. net. (See also p. 307 of this issue of Nature.) investigation of the effect of maturing conditions on their melting-point and rigidity. As a result of work by the Heating and Ventilating Research Association, together with that of other organizations, the factors conducive to large fuel savings in modern light-weight structures are now known at least qualitatively, and a simple approximate means of sizing the plant is being developed. A simple method of noise-rating has been specified which will enable manufacturers of ventilating and air-conditioning equipment to give the fan-noise output in identical form. The Association is also examining the ventilating and air conditioning of operating theatres.

Research by the British Hydromechanics Research Association on fluid sealing is concentrated on the mechanical or face seal, on moulded seals for reciprocating shafts, and on soft packings for stuffing box glands. Work on centrifugal pumps has involved use of a mathematical model in clarifying the nature of the fluctuating forces and of electrolytic tank methods for determining perfect fluid flow patterns in pumps, while a digital computing method has been used as an alternative to a graphical one for the analysis of complicated pumping systems. The basic engineering principles in the use of oil hydraulic machinery for transmitting mechanical power are being investigated and further model tests have been made on hydraulic problems in the pipe-work systems of the cooling-water circuits of large power stations. In a different field of industry, the 'Lacra' brass bobbin winder developed by the Lace Research Association is being satisfactorily used in Leavers lace factories, and a method has been devised to speed up that part of the process of removing floats or 'clips' from lace which is still carried out by hand, and to mechanize the final removal of the floats.

The Rubber and Plastics Research Association has made fundamental contributions to the theory of polymer molecule distribution and network formation and is able to record noteworthy progress in its investigations of the effect of water on unstrained glass-reinforeed plasties. The British Ship Research Association, which for five years from April 1, 1963, was awarded a minimum grant of $£ 300,000$, subject to a maximum of $£ 500,000$ with a further $£ 200,000$ on the basis of $£ 1$ per $£ 1$ on special contributions from ship owners and managers, continued full-scale trials of turbine machinery and investigated in several ships the cause of the deterioration in performance with time in service. Investigation of the increased wear of cylinder components associated with burning heavy residual oils indicates that an increase in cylinder liner temperature is most beneficial if the temperature is increased at the coolest portion of the liner. Problems of nuclear ship design, construction and operation are being investigated by a special team.

\section{THE ROCKEFELLER FOUNDATION}

$\mathrm{T}$ HE statement on futuro programme and policy issued last autumn by the Rockefeller Foundation described five principal interrelated areas in which the Foundation expects to concentrate its efforts during the immediate future. It is with these five areas that the first part of the president's review for 1963 "Promise and Progress" is mainly concerned, and, dealing first with the conquest of hunger, Dr. J. C. Harrar, recognizing that private philanthropy can only play a modest part, points out that the Foundation has chosen to assist this effort through co-operative efforts in the interrelated fields of education and the medical, agricultural and social sciences*. Moreover, it not only seeks to strengthen education in

* The Rockefeller Foundation Annual Roport for 1963, Pp. $319+$ xviii (The Rockefeller Foundation, 111 West Fifticth Street, New York, N.Y., 1964.) 